\title{
TESTING THE ACCEPTABILITY OF CHANGES TO ADVERTISING FASCIA FOR COMMERCIAL PROPERTIES IN HISTORIC URBAN AREAS IN CHINA AND JAPAN
}

\author{
日中の歴史的な町並における使用面積を基づいた屋外広告物の許容色 \\ Yi ZHUANG* and Sari YAMAMOTO** \\ 庄怡, 山本早里
}

\begin{abstract}
Focusing on areas of traditional architecture and historical importance in China and Japan, this paper is an investigation of the relationship between color and the extent to which the space of advertising fascia can be used for advertising before being perceived as too disruptive to the design of the building and the local ambience. Based on the Munsell color system, a survey was conducted, using questionnaires, to collate responses to different uses of hue, value and chroma combined with varying degrees of fascia coverage. The results showed that: 1) in cases when less than ten percent of fascia of individual buildings was used for advertising, changes in hue, value and chroma had a greater influence on the perceived visual impact of the area as a whole, compared to when changes were made to the amount of the fascia covered with advertising. 2) with chromatic color, changing the values had a stronger effect on people's perceptions than when changing the values of achromatic colors. 3) for chromatic color, when the fascia area used was $<3 \%$, value $<3$ and chroma < 6, similar levels of hue R, Y and B were considered to be acceptable, and higher than for hues G and P. 4) questionnaire respondents were more tolerant of increased areas of hue $\mathrm{Y}$ when used on Japanese wooden architecture.
\end{abstract}

\section{Keywords : Outdoor Advertising, Building Fascia, Color Perception, Fascia Area, Color Planning 屋外広告物, 看板, 色彩評価, 使用面積, 色彩計画}

\section{Introduction}

\subsection{Background and Objectives}

Following a 2014 survey of municipal guidelines for color plans for cities in Italy, France, Japan and China. As shown by the result1), regulation and control of urban colors was dominated by stipulating the usable range of colors and supplemented by adjusting the usable area, the use frequency of dominant colors, the area of the building façade used for color, etc. Among all the color plans we looked at, color planning was mostly determined by local regulations. Colors used in areas of historical significance were generally delineated in the strictest way.

However, there was also a significant demand for advertising to reflect the various color schemes used by businesses, brands, etc. In some of the cases, colors prohibited by local guidelines were nevertheless still used as per their original design, while in other cases they were modified them to conform with local ordinance. When original colors were used unmodified, in many cases this resulted in an overall lack of coordination and unpleasantly clashing colors ${ }^{2) a}$. Especially in areas of historical significance with relatively unified architectural features, new colors were rarely allowed. However, if the colors used in advertising were modified to comply with locally regulated color schemes, the original individuality and brand recognition would be lost.

Based on a policy of preserving historical ambience, color usage of adjacent blocks of the Gokushomachi area in Fukuoka ${ }^{3)}$ has been stipulated as follows: "colors with high chroma shall effectively only be used as accent colors rather than for large areas". Historic conservation areas in Hakodate also have specific color planning schemes, though: "Colors for window frames, columns, etc. are not regulated ${ }^{4}$. Historic regions in Nagoya, e.g.
* Doctoral Program in Art and Design, University of Tsukuba, M.Design

** Assoc. Prof., Faculty of Art and Design, University of Tsukuba, Dr.Eng.
筑波大学博士後期課程芸術専攻 修士(デザイン学) 筑波大学芸術系 准教授・博士 (工学) 
Yotsuya, Yamate street, etc. also have color planning regulations ${ }^{5}$. Colors outside of a prescribed limited area of the fascia can be used for accent colors. Kyoto strictly controls colors so that advertising fits in with the overall character of the city in the "regulation on landscape planning" clause of its building provisions ${ }^{6}$. However, as indicated in its revised regulations on outdoor advertising in $2015^{7}$, the allowable range of colors used for advertising hoardings was relatively open compared to overall building color schemes. Takayama Corp. were responsible for planning special landscape areas, indicating that primary colors should not be used for base colors of advertising hoardings ${ }^{8}$. Currently implemented color planning for historical conservation areas tend to allow the use of new colors to a limited degree. However, there is no definite stipulation about the lead-in methods. In some color plans, the hue of advertising boards is usually formulated based on $\mathrm{R} \sim \mathrm{Y}$ and other hues, without looking in detail at the perceived effect of the relationship between each hue and the size of the area it is used for. On the other hand, in China, there are no specific regulations about color planning for outdoor advertising.

With this in mind, this research was conducted on the relationship between surface area, hue, value and chroma. With reference to historic regions that have implemented color planning schemes, we focused on the use of small areas of color on the fascia of commercial properties, and establishing what was acceptable to onlookers in terms of accent color combined with various overall background color. To determine an effective color plan, we experimented with varying hues, values and chroma used in different sized proportions of fascia surface area and collated data on how these combinations were perceived by a sample demographic. We also explored what was considered an acceptable range of colors in when used in different fascia areas and how colors could be categorized.

\subsection{Previous Relevant Research}

Relevant research to this topic are as follows: 1) different approaches to urban color planning; 2) Clashing colors and how to avoid them; 3) relevant research on accent color; and 4) relevant regulations and evaluations of advertising fascia.

1) Comparing Different Urban Color Planning Procedures

Using Koto in Tokyo as an example, Ozaki et al. ${ }^{9)}$ put forward an urban color plan based on the surrounding natural environment and local traditions. Lee et al. ${ }^{10)}$ investigate native environmental colors of traditional villages in South Korea. They go on to look at color coordination in Makabe, Japan and devise a color matching scheme for the town ${ }^{11}$ that is sensitive to the local environment based on their research. Hayasi et al.12) extrapolate colors from the local historical environment, i.e., the color schemes used in traditionally manufactured goods and craft objects etc., and the color scheme was used for the area around Gifu Station. Yoshida ${ }^{13}$ 14) discusses the application of color in the formation of urban landscape, and different procedures for urban color planning. Sato ${ }^{15}$ proposes a color planning scheme based on regional differences.

Contemporary research in color planning mainly focuses on regional characteristics and overall coordination ${ }^{16}$. However, there is a lack of in-depth research on the relationship between colors used for particular areas, buildings and building features and what can be considered acceptable in terms of surface area used for advertising.

2)Clashing Colors and How to Avoid Them

In Sakahara et al. ${ }^{17)}$ a survey of people's impression of clashing colors has been carried out, from the perspective of architectural planning. Taniguchi et al. ${ }^{18)}$ is a discussion of regulating strong, contrasting colors used for buildings next to bodies of water. Nakano ${ }^{19)}$ looks at case studies of strong, uncoordinated colors in research on different approaches in color planning. Mitsuboshi investigates "public hazards of visually disruptive and uncoordinated colors ${ }^{20)}$ in his research and posits appropriate solutions based on several cases in which such colors occur.

Contemporary research mainly looks at what constitutes poor color coordination, and cases in which the regulation of color is badly handled. In response, Mitsuboshi suggests taking into account the surface area covered, height limitations, etc., but does not discuss the possible impact of the relationship between color and surface area.

3)Relevant Research on Accent Color

Kojima et al.21) is a discussion of the visual impact of accent colors through the use of contrasting values. In Yamamoto et al. ${ }^{22}$, the extent of the surface area used for accent colors is discussed as having a significant effect on visual impact. Kumazawa ${ }^{23)}$ uses simulations to compare different combinations of base and accent color, indicating the influence of accent colors on people's perception of their environment. As Kumazawa noted in 2014 ${ }^{24)}$, there is no generally accepted methodology for the planning of accent colors in Japan.

Prior research on accent colors mainly deals with the importance of the format and shape of advertising hoardings, but does not offer detailed discussion on the design and choice of accent colors.

4)Relevant Regulations and Evaluations of Advertising Fascia

Tsuji25) and Kato et al.26) discuss current restrictions on outdoor advertising and the use of color. Katsuya ${ }^{27)}$, Tsuchiya ${ }^{28)}$, Hirao ${ }^{29}$ et al. look at the overall impact that colors used in outdoor advertising have on an locale's visual character. Taniguchi et al. ${ }^{30)}$ performed a survey on colors used in outdoor advertising, and suggest that planning color in tandem with attention to a hoarding's location can have a positive effect on the urban landscape. Thus, colors should, to a certain degree, be permitted for places such as stations, shopping streets, etc. Watanabe et al. ${ }^{31}$ adopt aspects of the color matching scheme used in Kyoto for 
their color planning of outdoor advertising. According to Sato et a..32), compared to changes to relative surface area, differences in chroma have a greater impact on visual impression. To establish whether there is a conflict between color coordination and engaging visual interaction, $\mathrm{Maki}^{33)}$ experiments with changing colors used in advertising hoardings.

As proved by current research, advertising board colors greatly influences the overall visual impression of an urban environment. Surface area and chroma have a definite impact on the impression of the colors used in outdoor advertising. However, there is a lack of in-depth research on the various colors permitted in different surface areas.

\section{Methodology}

The survey questionnaire incorporated sectional elevations of
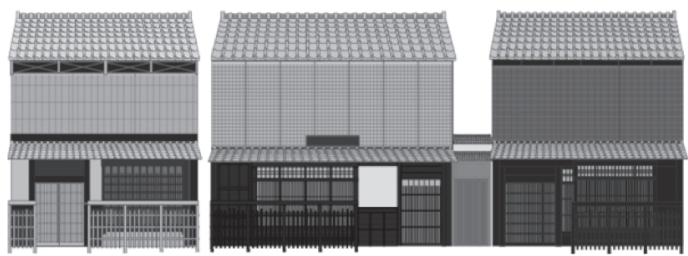

(a) Surface Area $1 \%, 10 \mathrm{~B} 3 / 4$
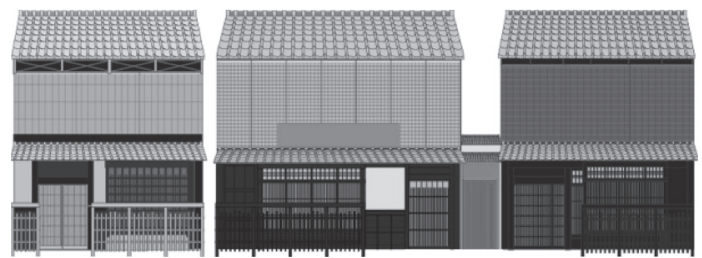

(b) Surface Area 5\%, 10R 6/4

Fig.1 Images Based on Kyoto Vernacular Wooden Architecture three building, in which the surface area and color of the fascia were shown in different configurations. Respondents were asked to give their impressions and evaluations to the different renderings. The buildings used in this survey were traditional vernacular properties constructed with wood frames, with white walls. Given the similarities and differences between Japanese and Chinese architecture, this study used model structures based on traditional wooden-frame buildings in Kyoto, Japan and white-walled buildings in Zhouzhuang, China.

In this study the size and color of the fascia above the pent roof of the first floor were varied. Fig. 1 are designs based on traditional Japanese wood frame buildings from Kyoto, while those in Fig. 2 were based on white-walled buildings in Zhouzhuang. The research objective was to establish the extent to which fascia could be used for advertising before provoking a

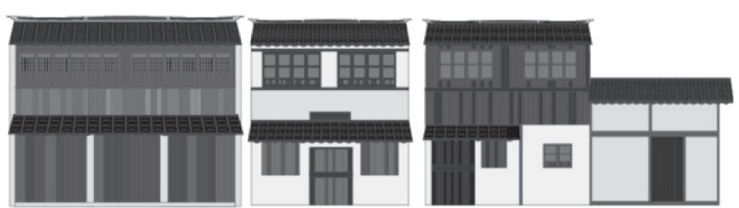

(a) Surface Area 1\%, 10B 3/4

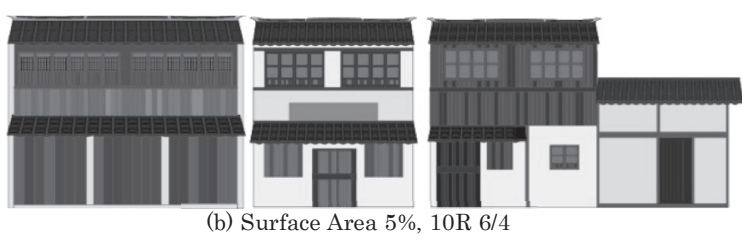

Fig. 2 Images Based on the White-wall Vernacular Architecture in Zhouzhuang

Table 1 Building Color

\begin{tabular}{|c|c|c|c|c|c|c|}
\hline & \multicolumn{3}{|c|}{ Japan } & \multicolumn{3}{|c|}{ China } \\
\hline & Left & Middle & Right & Left & Middle & Right \\
\hline Roof & 10B $8 / 1$ & $5 \mathrm{~PB} 8 / 3$ & $5 \mathrm{~PB} 8 / 3$ & N3;N6 & N3; N6 & N3; N6 \\
\hline Exterior wall & $\begin{array}{c}2.5 \text { YR } 2 / 2 ; 5 \text { YR } 3 / 6 ; \\
10 \text { YR } 8 / 8\end{array}$ & $\begin{array}{c}\text { 5R 2/2; } 10 \mathrm{YR} 2 / 2 ; \\
5 \mathrm{Y} 9 / 4\end{array}$ & 5 YR $2 / 2$ & $2.5 \mathrm{Y} 9 / 1 ; 10 \mathrm{YR} 5 / 4$ & N8; 10YR 9/2 & $\begin{array}{c}\text { N7; N8; } \\
\text { 7.5YR 8/4 }\end{array}$ \\
\hline Window & $2.5 \mathrm{Y} 9 / 4 ; 2.5 \mathrm{YR} 2 / 2$ & $5 \mathrm{R} 2 / 2 ; 10 \mathrm{YR} 8 / 2$ & $\begin{array}{l}\text { 10YR 3/4; } \\
\text { 10YR 5/4 }\end{array}$ & $5 \mathrm{R} 4 / 4$ & $\begin{array}{c}10 \text { YR } 5 / 3 ; 10 \text { YR } 4 / 4 ; \\
10 \text { YR } 3 / 3\end{array}$ & $10 \mathrm{YR} 3 / 4 ; 10 \mathrm{YR} 4 / 4$ \\
\hline Door & 5YR 3/6; 2.5YR 2/2 & $5 \mathrm{R} 2 / 2$ & 5YR $2 / 2$ & 2.5 YR 4/6; 2.5 YR 3/4; & 10YR 4/4; 10YR 3/3 & 10YR 3/4; 10YR 4/4 \\
\hline Other & 5 YR $3 / 6 ; 2.5$ YR $2 / 2$ & $\begin{array}{c}\text { 5R 2/2; } 7.5 \text { YR 5/8; } \\
\text { 5YR 6/10 }\end{array}$ & & & - & \\
\hline
\end{tabular}

Table 2 Colors and Surface Area

\begin{tabular}{|c|c|c|c|c|c|c|c|c|}
\hline & Value & Value & Value & & \multicolumn{4}{|c|}{ Chroma } \\
\hline & 3 & 6 & 8 & 3 & 6 & 10 & 11 & 12 \\
\hline $\mathrm{R}$ & $10 \mathrm{R} 3 / 4$ & $10 \mathrm{R} 6 / 4$ & $10 \mathrm{R} 8 / 4$ & & 10R 5/6 & 10R 5/10 & & 10R $5 / 12$ \\
\hline AREA(\%) & $1 \%, 5 \%$ & $1 \%, 5 \%$ & $1 \%, 5 \%$ & & $1 \%, 5 \%, 8 \%, 10 \%$ & $1 \%, 5 \%, 8 \%, 10 \%$ & & $1 \%$ \\
\hline $\mathrm{Y}$ & $10 Y 3 / 4$ & 10Y 6/4 & $10 Y 8 / 4$ & & $10 Y 5 / 6$ & $10 \mathrm{Y} 6 / 10$ & $10 \mathrm{Y} 8 / 11$ & \\
\hline AREA(\%) & $1 \%, 5 \%$ & $1 \%, 5 \%$ & $1 \%, 5 \%$ & & $1 \%, 5 \%, 8 \%, 10 \%$ & $1 \%, 5 \%, 8 \%, 10 \%$ & $1 \%, 5 \%$ & \\
\hline $\mathrm{G}$ & & & & 10G $5 / 3$ & 10G 5/6 & 10G 5/10 & & \\
\hline AREA(\%) & & & & $1 \%, 3 \%, 5 \%$ & $1 \%, 3 \%, 5 \%$ & $1 \%, 3 \%$ & & \\
\hline$B$ & $10 \mathrm{~B} 3 / 4$ & 10B $6 / 4$ & 10B $8 / 4$ & 10B $5 / 3$ & 10B 5/6 & 10B 5/10 & & \\
\hline $\operatorname{AREA}(\%)$ & $1 \%, 5 \%$ & $1 \%, 5 \%$ & $1 \%, 5 \%$ & $1 \%, 5 \%, 8 \%, 10 \%$ & $1 \%, 5 \%, 8 \%, 10 \%$ & $1 \%$ & & \\
\hline$P$ & & & & $10 \mathrm{P} 5 / 3$ & $10 \mathrm{P} 5 / 6$ & & & \\
\hline AREA(\%) & & & & $1 \%, 3 \%, 5 \%$ & $1 \%, 3 \%, 5 \%$ & & & \\
\hline $\mathrm{N}$ & N3 & N6 & N8 & & & & & \\
\hline AREA(\%) & $1 \%, 5 \%$ & $1 \%, 5 \%$ & $1 \%, 5 \%$ & & & & & \\
\hline
\end{tabular}


negative reaction. Therefore, in this experiment, the background color was used to directly portray the surface area of the fascia. In addition to this, before being shown the images, it was indicated to respondents that advertising fascia had been newly added in the area, thus the respondents should give their evaluations based on the premise that the fascia would carry advertising.

In the field, we used JIS color charts to measure the the actual coloration of the target buildings and apply real-world color data in the pictures used in the trial. The building colors are shown in Table 1.

From a preparatory test ${ }^{34}$, it was found that different hues affected the degree to which respondents' accepted the use of fascia for advertising, and tolerance decreased as chroma increased. Also, the acceptance of colors decreased as surface area increased, and the mean value of acceptability of advertising fascia would be less than 0 when the surface area exceeded $10 \%$, therefore, the fascia surface area was kept to under $10 \%$ of the building façade and the colors used were varied based on changing the hue and surface area.

The fascia sizes used in this trial were $1 \%, 3 \%, 5 \%, 8 \%$ and $10 \%$ of the actual building façades.

According to the Munsell color system, hues are divided into R, Y, G, B and P, each of which contains low, moderate and high value colors. Three chroma were selected for each hue with the highest chroma being the highest point on the spectral locus. As shown in table 2, 26 colors were combined with different surface areas for the trial.

For each image, there were three factors to evaluate: conformity to traditional color usage, coordination and whether the fascia color/size combination was acceptable to viewers given the architectural context. These were evaluated using a 7 -stage semantic differential rating scale, and values - $3,-2,-1,0,1,2$ and 3 , were collated for each response. Negative numbers indicated a negative reaction, while positive numbers represent respondents' positive acceptance of a design.

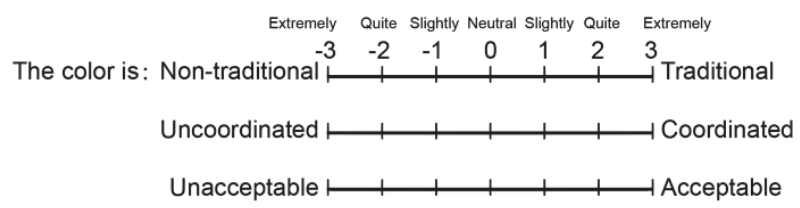

Fig.3 Evaluation Items

Respondents were categorized by nationality, profession, whether they had actually seen the target buildings in situ and the degree of their positive or negative reaction to fascia colors.

Altogether, there were 87 participants in this trial, i.e. 42 Japanese college students and 45 Chinese students studying in Japan. Uncompleted questionnaires, and those in which all questions had received the same response, were discarded. There was a combined total of 80 valid questionnaires, which constituted the database. The setup for filling in the questionnaire is shown in fig.4.

The trial was carried out in a standard D65 luminous environment and at an illumination intensity of 1200lx on desk surfaces.

We used an 8-color inkjet printer to print the images and verified the colors using JIS color charts after printing the images.

In order to clearly indicate the variations in fascia surface area and color, these were depicted on elevations of the building façades. With the premise of providing a complete view of the color matching applied to the three buildings and a clear sense of the changes to the fascia size, the images used in the trial were $15 \mathrm{~cm} \times 30 \mathrm{~cm}$.
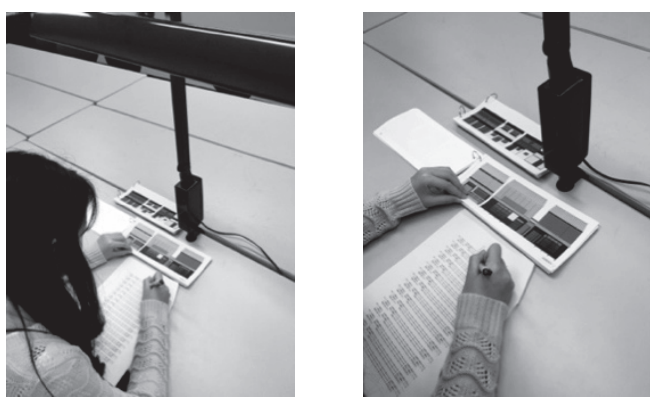

Fig.4 A questionnaire Being Completed

66 images were used with different variations and fascia size for each group of buildings. As there were two sets of buildings, there was a total of 132 images. These were shown to the respondents randomly, and questionnaires took 30 minutes to complete.

\section{Analysis of Responses}

To be able to confirm the distribution of the data, box plotting and mean value were used in the analysis. However, when the mean and median values were significantly different, we analyzed the distribution of the data. A large difference had arisen between mean and median values in several cases, but both of them were in positive or negative. In addition, the bimodality of data had not been appeared. Based on this, mean values were used to determine whether the colors/size were considered acceptable through the $\mathrm{P}$ value and with positive and negative changes of the mean value.

\subsection{Analysis of Respondent Backgrounds}

Firstly, responses were collated according to respondents' background attributes. Table 3 shows the range of acceptable size and color combinations for Chinese and Japanese respondents on the two different types of building. There was no significant difference in response, on the basis of country of origin of either the respondent or the building, or, in fact, any other background 
Table 3 Acceptability of Fascia Colors on Kyoto and Zhouzhuang Buildings by Chinese and Japanese Respondents (chroma at surface area of $1 \%$ )

\begin{tabular}{|c|c|c|c|c|c|c|c|c|c|c|c|c|c|c|c|}
\hline & \multirow{2}{*}{$\begin{array}{l}\text { Hue } \\
\text { Chroma } \\
\end{array}$} & \multicolumn{3}{|l|}{$\mathrm{R}$} & \multicolumn{3}{|l|}{$\mathrm{Y}$} & \multicolumn{3}{|l|}{$\overline{\mathrm{G}}$} & \multicolumn{3}{|l|}{$\mathrm{B}$} & \multicolumn{2}{|l|}{$\mathrm{P}$} \\
\hline & & 6 & 10 & 12 & 6 & 10 & 11 & 3 & 6 & 10 & 3 & 6 & 10 & 3 & 6 \\
\hline \multirow[t]{2}{*}{ Japanese Building Design } & Japanese respondents & 0.48 & -0.10 & -1.03 & 0.08 & 0.53 & -0.73 & 0.13 & -1.2 & -1.43 & 0.70 & 0.08 & -1.75 & 0.08 & -0.70 \\
\hline & Chinese respondents & 0.95 & -0.58 & -1.45 & 0.28 & 0.03 & -0.79 & -0.05 & -1.08 & -1.53 & 1.00 & -0.05 & -1.53 & -0.03 & -1.08 \\
\hline \multirow{2}{*}{ Chinese Building Design } & Japanese respondents & 1.1 & -0.03 & -1.10 & 0.75 & 0.30 & -0.93 & 0.45 & -1.13 & -1.48 & 1.20 & 0.40 & -1.75 & 0.13 & -0.70 \\
\hline & Chinese respondents & 0.63 & -0.75 & -1.73 & 0.35 & -0.13 & -1.33 & 0.45 & -1.03 & -1.53 & 1.18 & 0.10 & -1.43 & 0.63 & -1.05 \\
\hline$* \mathrm{p}<0.05 \quad * * \mathrm{p}<0.01$ & & & & & & & & & & & & & & & \\
\hline
\end{tabular}
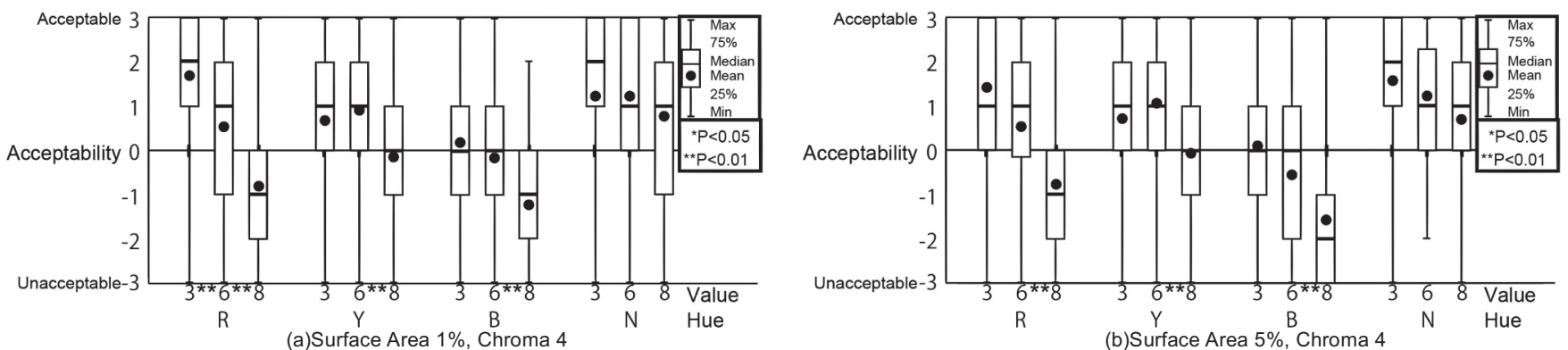

Fig. 5 Acceptability for Fascia Colors of Different Values on Kyoto Wood-Frame Buildings
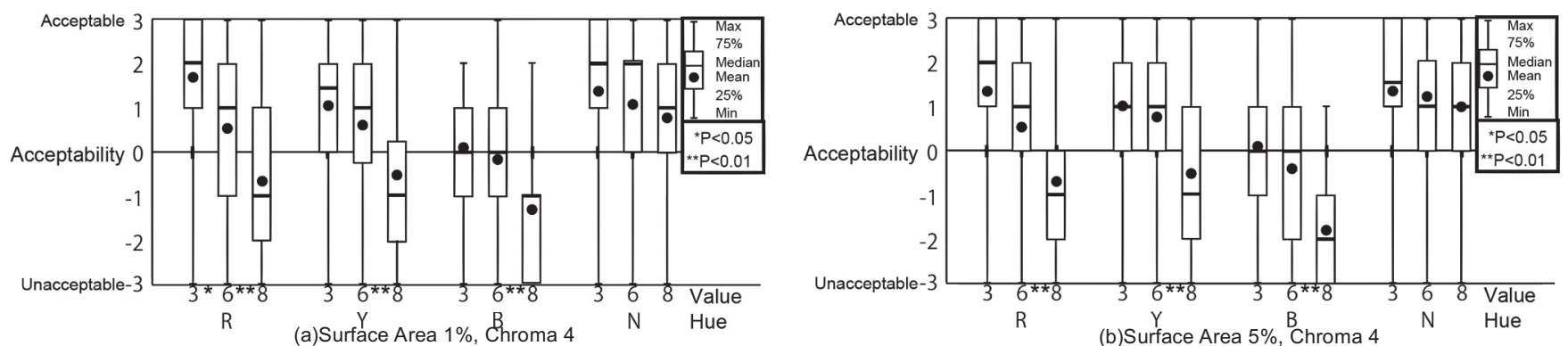

Fig.6 Acceptability for Fascia Colors with of Different Values on Zhouzhuang White-wall Buildings

factors. In other words, the trial results were consistent, and therefore the mean value of the 80 valid questionnaires was used for evaluation.

\subsection{Correlation of Responses}

As mentioned, each image was evaluated based on three factors: traditional, coordinated and Acceptable. When $\mathrm{p}<0.01$, for the Kyoto buildings, the correlation coefficient between traditional color matching and values perceived as acceptable was 0.976. Between coordinated color matching and acceptable values it was 0.984 . For the Zhouzhuang buildings, the correlation coefficient between traditional color matching and acceptable values it was 0.961 , and between coordinated color matching and acceptable values, 0.980. Traditional color matching and coordinated color matching strongly correlated to values considered acceptable to respondents.

\subsection{Varying Fascia Size and Value}

Fig.5 and 6 show ranges of acceptability for fascia colors of different values. With a fascia surface area of $1 \% \sim 5 \%$ of the building façade, chroma 4 , hue R, Y and B, there were significant differences for values between 6 and 8 for both sets of buildings. When the value was about 8 , the acceptability rating for new fascia colors went into the negatve. However, there was no such change for achromatic color, N. Therefore, when the fascia size was less than $5 \%$ of the building façade, if the value of chromatic colors was more than 6 , then the colors were deemed unacceptable. However, there was no value restriction when it came to achromatic colors.

In fig.6(a), a significant difference can be seen between mean and median values of color N6. From an evaluation of the data, it can also be seen that $77.5 \%$ of the answers were concentrated in acceptability range of $1 \sim 3.20 \%$ of the answers were concentrated in the acceptibility range of $-1 \sim-2$. This made the mean value less than the median value of $\mathrm{N} 6$.

\subsection{Fascia Surface Area and Chroma}

Fig. 7 and 8 show respondents' evaluation of fascia colors with different chroma. A value of 5 was mostly used in this part except $10 \mathrm{Y} 6 / 10$ and $10 \mathrm{Y} 8 / 11$. Fascia sizes were divided into two ranges, $1 \% \sim 5 \%$ and $8 \% \sim 10 \%$, and chroma of each hue were evaluated for these two groups.

When the fascia was within the range $1 \% \sim 5 \%$, there were significant differences between hue R, chroma 6 and 10 in both the Japanese and Chinese buildings. When the chroma was 10 , the respondent reaction was negative, i.e. the layouts were not considered an acceptable fit to the environment. A significant difference in judgment of hue Y occurred when the chroma was between 10 and 12, i.e. the color of hue $\mathrm{Y}$ was deemed acceptable when the chroma was less than 10. A significant change in 

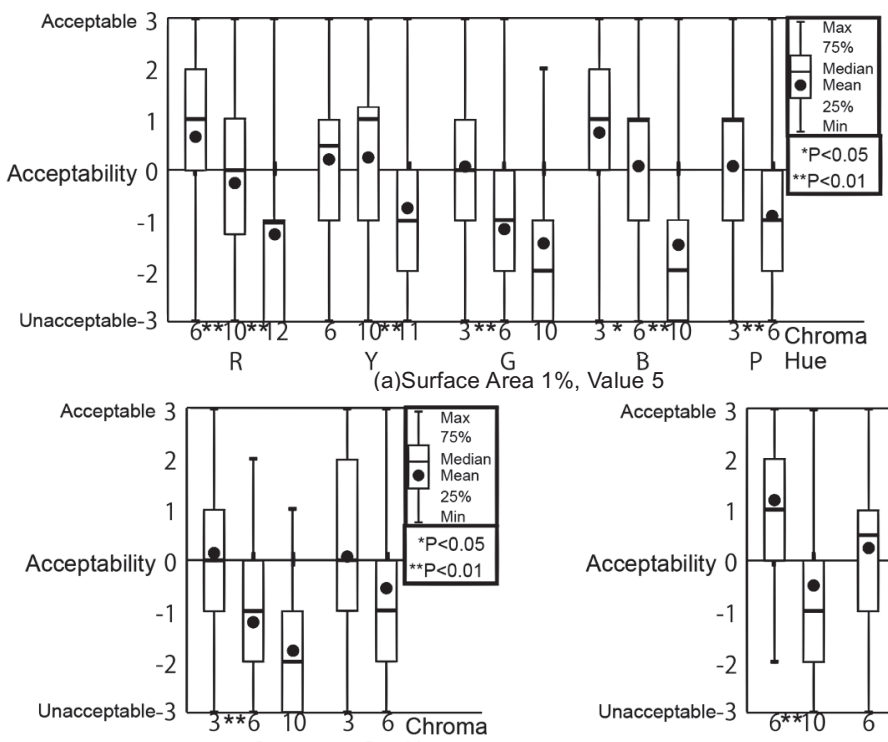

(b) Surface Area $3 \%$, Value 5

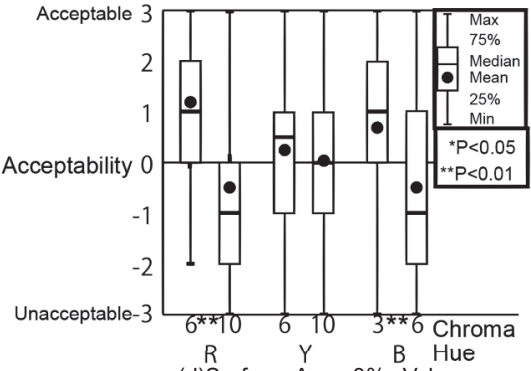

R
(d) Surface Area $8 \%$, Value

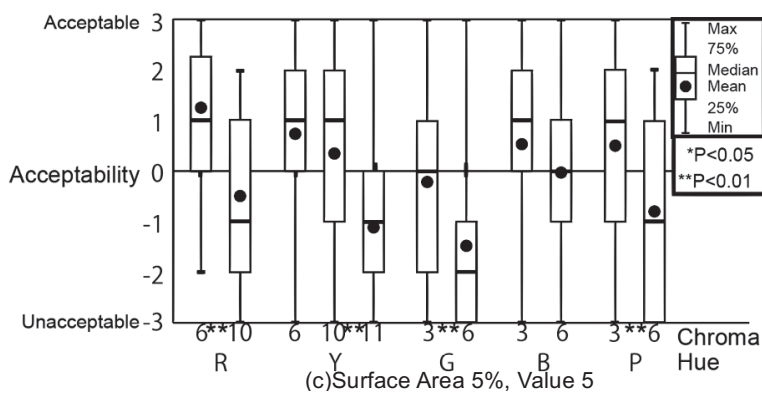

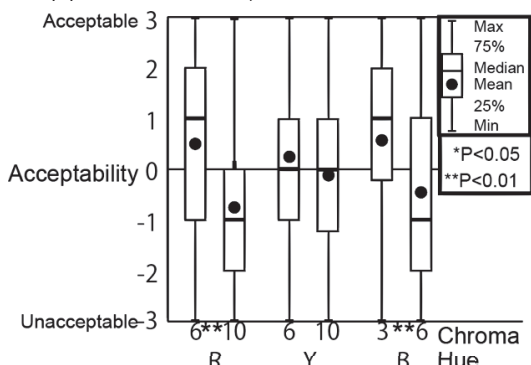

Fig.7 Acceptability for Fascia (e)Surface Area 10\%, Value 5

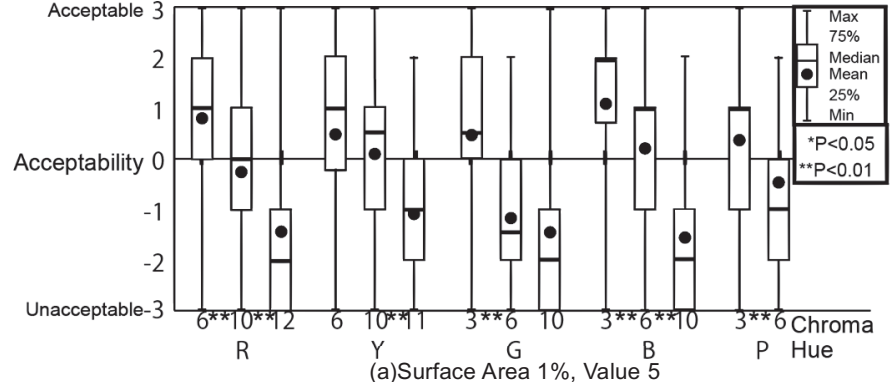

(a)Surface Area $1 \%$, Value 5

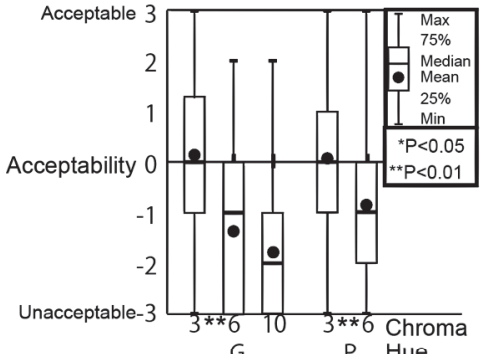

(b)Surface Area $3 \%$, Value 5

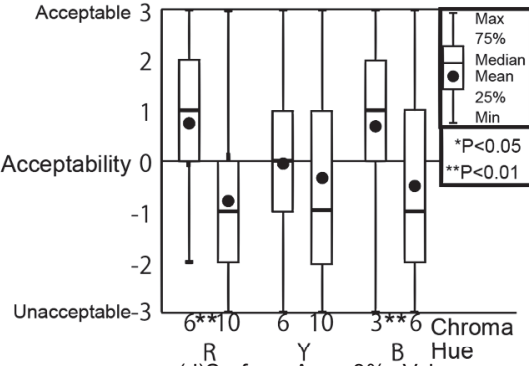

(d) Surface Area $8 \%$, Value

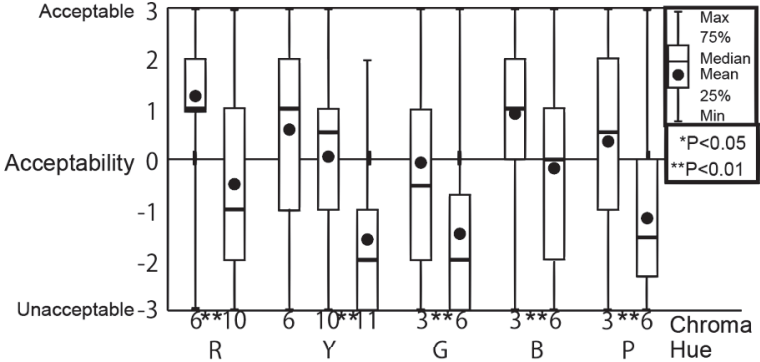

(c) Surface Area $5 \%$, Value 5 P Hue

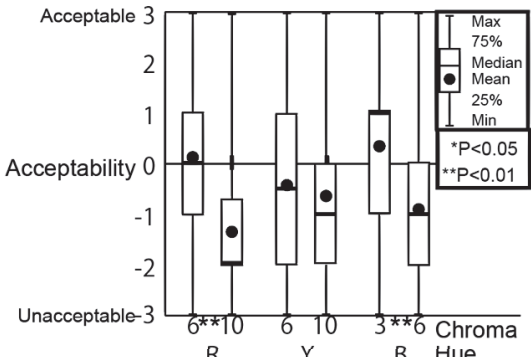

(e)Surface Area $10 \%$, Value 5

Fig. 8 Acceptability for Fascia Colors of Different Chroma on Zhouzhuang Buildings

reaction to color G occurred between chroma 3 and 6 . Thus, the chroma of hue $\mathrm{G}$ was considered acceptable when it was less than 3 . As for hue B, when the fascia was increased to $5 \%$ of the façade, there was no significant difference between chroma 3 and 6 for the Japanese buildings; however, there was a quite different response to the same colors when applied to the Chinese buildings. A significant change in reaction to hue $P$, with the mean value of responses going from positive to negative, occurred with chroma between 3 and 6 . Therefore, colors of hue $\mathrm{P}$ with chroma of less than 3 were considered acceptable.

When the fascia was in the $8 \% \sim 10 \%$ range, the change in reaction to hue $\mathrm{R}$ was between chroma 6 and 10. There were no changes in reaction to hue Y. However, with a fascia of $10 \%$, value 5 and chroma 6 , there were significant differences in reaction to hue $\mathrm{Y}$ depending on which buildings were being considered;
Acceptance of the color was greater with the Japanese buildings than with the Chinese buildings. Reaction to B changed from chroma 3 to 6 . Thus, when the fascia size was greater than $5 \%$, hue $\mathrm{R}$ was considered acceptable with chroma 6 , hue $\mathrm{Y}$ with chroma 10, and hue B was considered acceptable with chroma 3.

\subsection{Fascia Size and Hue}

With value and chroma constant, reaction to changes in hue could be evaluated. Results were mainly used a way to categorize hues. If there was no significant difference in reaction between two hues, the two hues could then be considered the same in value or chroma. As shown in Table 2, colors and fascia size are compared with the same value and chroma in this section.

In the observation of value, there were major differences in response between chromatic and achromatic colors. For the Japanese buildings, when the value was 6 , the response to hue B 

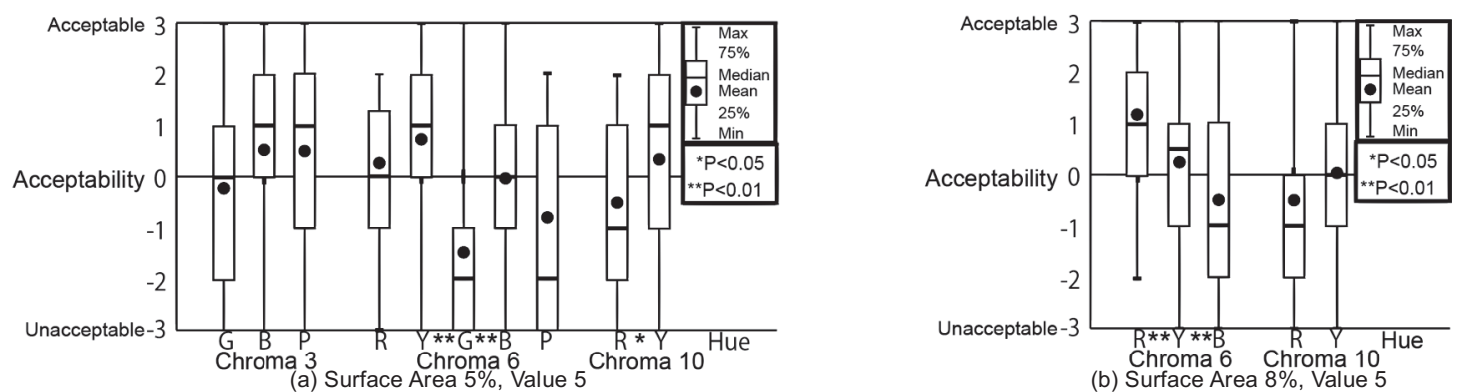

Fig. 9 Acceptability of Hue based on Chroma of Kyoto Buidings
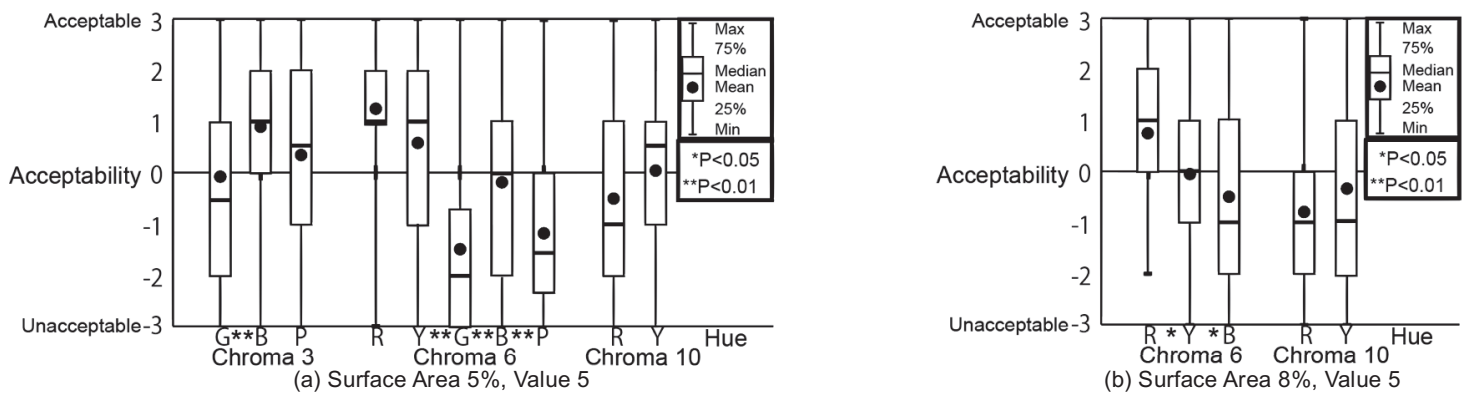

Fig.10 Acceptability of Hue based on Chroma of Zhouzhuang Buildings

Table 4 Reactions to Chroma Variations (Chroma)

\begin{tabular}{|c|c|c|c|c|c|c|c|c|c|c|c|c|c|c|c|}
\hline & Hue & \multicolumn{3}{|l|}{$R$} & \multicolumn{3}{|l|}{$\mathrm{Y}$} & \multicolumn{3}{|l|}{ G } & \multicolumn{3}{|l|}{$\mathrm{B}$} & \multicolumn{2}{|l|}{$\mathrm{P}$} \\
\hline & Chroma & 6 & 10 & 14 & 6 & 10 & 12 & 3 & 6 & 10 & 3 & 6 & 10 & 3 & 6 \\
\hline \multirow[t]{2}{*}{$1 \%$} & Architecture of J apan & 0.71 & -0.34 & -1.24 & 0.18 & 0.28 & -0.75 & 0.04 & -1.14 & -1.48 & 0.85 & 0.01 & -1.64 & 0.03 & -0.89 \\
\hline & Architecture of China & 0.86 & -0.39 & -1.41 & 0.55 & 0.09 & -1.13 & 0.45 & -1.08 & -1.50 & 1.18 & 0.25 & -1.59 & 0.38 & -0.88 \\
\hline \multirow[t]{2}{*}{$3 \%$} & Architecture of J apan & $\pi$ & $x_{3}$ & & 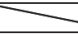 & X & $\mathrm{C}$ & 0.13 & -1.25 & -1.78 & & & & 0.05 & -0.68 \\
\hline & Architecture of China & 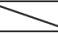 & Y & 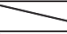 & - & $x_{1}$ & $\gamma$ & 0.13 & -1.39 & -1.89 & . & 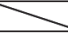 & & 0.03 & -0.93 \\
\hline \multirow[t]{2}{*}{$5 \%$} & Architecture of J apan & 1.21 & -0.51 & S & 0.80 & 0.39 & -1.08 & -0.18 & -1.40 & $\mathrm{X}^{2}$ & 0.65 & -0.06 & 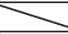 & 0.51 & -0.84 \\
\hline & Architecture of China & 1.26 & -0.66 & - & 0.63 & 0.08 & -1.58 & -0.30 & -1.41 & & 0.91 & -0.24 & & 0.30 & -1.18 \\
\hline \multirow[t]{2}{*}{$8 \%$} & Architecture of J apan & 1.18 & -0.59 & - & 0.25 & 0.03 & ( & 三 & S & 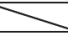 & 0.73 & -0.60 & 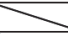 & 工 & \\
\hline & Architecture of China & 0.76 & -0.83 & 7 & -0.03 & -0.44 & & & $x$ & 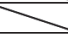 & 0.70 & -0.76 & & & \\
\hline \multirow[t]{2}{*}{$10 \%$} & A rchitecture of J apan & 0.49 & -0.81 & & $0.31^{*}$ & -0.25 & & & & & 0.65 & -0.40 & & & \\
\hline & Architecture of China & 0.14 & -1.35 & S & $-0.41 *$ & -0.70 & & & & 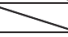 & 0.30 & -0.90 & & & \\
\hline
\end{tabular}

was similar of that to hues $\mathrm{R}$ and $\mathrm{Y}$; when the value was greater than 6 , there were relatively large differences in reaction between hues B and R Y and N. For the Chinese buildings, when the value was 3 , there were significant differences in reaction to hue $R \sim Y$ and hue $\mathrm{B}$, even though responses to both were greater than 0 , in the positive range. Therefore, when categorizing value, if the fascia was less than $5 \%$ of the façade, the hues could be divided into three groups $\mathrm{R} \sim \mathrm{Y}, \mathrm{B}$, and $\mathrm{N}$ for the purposes of planning value.

Regarding chroma, evaluation was made by dividing the fascia sizes into two ranges: $1 \% \sim 5 \%$ and $8 \% \sim 10 \%$. With the fascia at less than $5 \%$, as we can see from data in Figs. 9 and 10, when the chroma was 6 , the responses to hues R, Y and B were similar to but different from that to hues G and P. When the chroma was greater than 10 , only the average value of the response to hue $\mathrm{Y}$ was greater than 0 . Therefore, when the fascia was less than $5 \%$ and the chroma was no more than 6 , the hues could be divided into two groups: R Y and B, and G and P. If the chroma is 10, hue Y should be considered different from other hues.

When the fascia was between $8 \%$ and $10 \%$ and chroma was 6 , there were significant differences in reaction to hues $\mathrm{R}, \mathrm{Y}$ and $\mathrm{B}$; hue $\mathrm{R} \sim \mathrm{Y}$ was considered acceptable, but reaction to hue $\mathrm{B}$ was negative. Thus, when the fascia was between $8 \%$ and $10 \%$, chroma should be considered independently.

\subsection{Fascia Size and Color}

There were different responses to the same color when the fascia size was varied between $1 \%$ and $10 \%$. Results showed only color 10R 5/10, 10B 5/6 elicited a significantly different reaction to the Chinese buildings, when the fascia was between $1 \%$ and $10 \%$. Therefore, the size of the fascia had less influence on the overall color matching. The planning of fascia size and the classification of colors in this research were mainly based on the evaluation of changes to hue, value and chroma.

\subsection{Comparative Analysis}

Finally, a comparative analysis was made of the significant differences in reaction to the different color plans for the Chinese and Japanese buildings. As shown in Table 4, there was a significant difference in respondents' reactions to fascia color design for the Chinese and Japanese buildings only for the combination of $10 \%$ surface area and $10 \mathrm{Y} 5 / 6$. However, for other combinations, there is no difference in reaction on the basis of region, implying a certain congruity between the visual 
characteristics of the vernacular architecture of the two countries.

\section{Conclusion and Discussion}

In this trial, no differences in opinion could be discerned as resulting from different respondent attributes. In other words, attitudes to color design were not related to respondent's personal characteristics.

There was a strong correlation between traditional color matching, color coordination and evaluation factors. That is to say, if respondents thought color matching accorded with traditional or coordinated color matching, the likelihood of being colors being considered acceptable would also increase.

The survey revealed that the degree of approval of fascia color was similiar for Japanese and Chinese building types, except for color $10 \mathrm{Y} 5 / 6$ with a fascia size that was $10 \%$ of the total building façade.

Regarding value, acceptable values of $\mathrm{R}, \mathrm{Y}, \mathrm{B}$ and $\mathrm{N}$ were investigated, when chroma was 4 . When the values of $\mathrm{R}, \mathrm{Y}$ were greater than 8 and $\mathrm{B}$ was greater than 6 , the acceptability ratings of chromatic colors were all less than 0 . In other words, they were considered unacceptable. However, achromatic colors were not as significantly affected by changes in value. Generally, the use of achromatic colors in regions of historical value meet with comparatively high levels of approval.

For chromatic color, when fascia size was less than $3 \%$ of the façade, the value was less than 3 and chroma less than 6 , reaction to hues $\mathrm{R}, \mathrm{Y}$ and $\mathrm{B}$ were comparable. However, acceptance ratings for hues $\mathrm{G}$ and $\mathrm{P}$ were relatively lower.

As respondents' evaluations of acceptable color and fascia size for the two types of buildings' was not dissimilar, the following conclusions were reached (See Table 5).

However, differences in acceptability for the two types of buildings occurred for hue Y. When the facia was $10 \%$, with value 5 and chroma 6, acceptance of hue $Y$ was greater for the Japanese buildings than when used with the Chinese buildings. Since evaluation was in the negative range for the Chinese buildings, a comparatively larger surface area of hue $\mathrm{Y}$ was deemed acceptable for the buildings in Japan.

Table 5 Acceptable Color Usage in Areas of Historical Value

\begin{tabular}{l|l|l|l|l|l}
\hline \hline & Value(chroma 4) & Chroma & \multicolumn{1}{l}{} \\
\hline Area & $<5 \%$ & $<10 \%$ & $<3 \%$ & $<5 \%$ & $<10 \%$ \\
\hline $\mathrm{R}$ & $<6$ & - & & & $<6$ \\
\hline $\mathrm{Y}$ & $<6$ & - & & $<10$ & $\mathrm{X}^{*}$ \\
\hline $\mathrm{G}$ & - & - & & Below 3 & - \\
\hline $\mathrm{B}$ & $<3$ & - & $<6$ & $<3$ & $<3$ \\
\hline $\mathrm{P}$ & - & - & & $<3$ & - \\
\hline $\mathrm{N}$ & $\circ$ & - & & & \\
\hline
\end{tabular}

When the fascia was less than $10 \%$ of the façade, there were significant differences in reaction to hue, value and chroma. However, there were no major differences in opinion for changes in fascia size with the same color, except $10 \mathrm{R} 5 / 10$ and $10 \mathrm{~B} 5 / 6$ when applied to the Chinese buildings. In other words, when the fascia was less than $10 \%$, the colors used had a greater influence on opinions of overall color matching as opposed to fascia size.

Currently, colors with a relatively high acceptability is concentrated on 'natural' background colors, e.g. $\mathrm{R} \sim \mathrm{Y}$ earth and wood colors and the B stone color system, for both Japanese and Chinese buildings. Most vernacular architecture in areas of historical significance is constructed using natural materials, and the uniformity between materials and color systems has also been preserved. Furthermore, in Japan, noren, colored using natural dyes, are often used in traditional architecture. Thus, for historical areas with a comparatively uniform style, inherited colors of various traditional materials are more likely to be considered acceptable.

As for colors used for fascia in areas of traditional vernacular architecture, the use of billboards usually prohibited, though some areas allow the use of accent colors and advertising hoardings within a given range. In terms of color planning, basic colors are preferred in some areas, e.g. dark brown, and relevant applications need to be submitted before the colors are actually used. Some regions only permit a relatively narrow usable range of colors within certain areas. This research has been aimed at showing that the use of colored fascia in areas of traditional vernacular architecture can be acceptable. Results showed that colors do not have to be so strictly limited in such areas. Furthermore, colors can be used more freely and effectively according to their particular characteristics.

The acceptability of colors was considered using an average value 0 as the standard. However, for some conservation areas, further verification should be conducted using an increased average value, e.g. using an average acceptance value of 1 . In addition, the evaluation standard could be relatively lower for areas of less regulation, or districts adjacent to conservation areas.

Considering regional features and differences in building color, evaluations of traditional wooden buildings in Kyoto and whitewall buildings in Zhouzhuang were collated. As indicated by the resulting data, the acceptability of colored fascia for the two types of architecture were consistent. Therefore, we concluded that the experimental data had certain generality on historical blocks of wooden building and white walls. In addition, owing to consistent acceptability of two buildings, we proposed a possibility that the acceptability of colored fascia was determined by atmosphere of historical urban but not the color of the building. However, further research will be conducted on other types of architecture.

The color planning trial was conducted with printed images of dimensions $15 \mathrm{~cm} \times 30 \mathrm{~cm}$. Considering the area effect of the color, 
value and chroma seem high when an area becomes large ${ }^{35}$. We speculated that the allowable limit of the color may had a certain deviation when it used in buildings. However, the tendency findings of color using can be applied to actual use. Therefore, acceptability should be verified by actual use.

Variations in value and chroma were investigated, and in the experimentation with value, only colors with chroma 4 were used. But the result was proved in the experiment of "fascia surface area and chroma". For example, it was found that the color Y with value 6 (chroma 4) was considered acceptable. However, 10Y $6 / 10$ was used in a chroma variation and this was also considered acceptable. The value data can therefore be considered to be reliable to some extent, however, verification of the matching of value and chroma should be pursued in future research.

Fascia used in this trial were commonly-used rectangular boards and the trial was carried out based on the background color of the boards. Further research needs to be done on other possible formats and the use of text. In future research examples of actual fascia will be used to investigate form, combinations of text and background color, the relationship between fascia design and color, etc.

\section{Acknowledgement}

This research is supported by Grant-in-Aid for Scientific Research (Issue number: 15K00677; Project Leader: Sari Yamamoto)

\section{References}

1）庄怡, 山本早里: 景観計画における色のコントロール方法の抽出一イタ リア、フランス、日本、中国における町の色彩計画をもとに一, 日本建 築学会大会学術講演梗概集，環境工学 I, pp. 487-488，2015.9

2) 三星宗雄: 日本における騒色公害とその解決, 神奈川大学人文学研究所 報 46，pp. $35-51 ， 2011.10$

3）福岡市景観計画地域別編一御供所地区都市景観形成地区，p. 6，2015

4）都市景観形成地域の景観デザイン指針（函館市），pp. 33-34，2012

5）名古屋市景観計画，pp. 37-38，2011

6）京の景観ガイドライン建築デザイン編，pp. 2-14 2-16, 2013

7）京の景観ガイドライン広告物編，pp. 2-17，2015

8）高山市屋外広告物条例個別基準，pp. 5-8，2015

9）尾崎真理，金敬仁，小林正美 : 風土に基づいた都市色彩計画に関する研 究一東京都江東区を事例として一, 日本建築学会計画系論文集, 第 511 号, pp. 147-152, 1998.9

10）李錫賢, 山本早里, 三村翰弘 : 韓国の伝統的な村落における風土的環境 色彩, デザイン学研究，第 52 号, pp. 23-30, 2005.7

11）李錫賢，野中勝利：地域と調和した景観色彩に関する研究一真壁の伝統 的な町並を事例としてー, 日本建築学会大会学術講演梗概集, 都市計画, pp. 171-172, 2006. 9

12）林英光，森旬子，萩原康予：風土・伝統色彩の都市景観一の導入一JR 岐 阜駅北口再開発のデザインと色彩, 日本色彩学会誌, 第 35 号, pp. 9091, 2011

13）吉田慎悟 : 環境色彩デザインの手法一まちの色をつくる, 建築資料研究 社, 1998. 10

14）吉田慎悟：景観法を活用するための環境色彩計画，丸善，2005.9

15）佐藤邦夫：風土色と喍好色，青娥書房， 1986

16）山本早里：地域の個性を重視した環境色彩づくり，日本色彩学会誌，第 28 号, pp. 178-179, 2004

17）坂原弘也 : 実態調查による「騒色」のイメージ色について, 日本色彩学
会誌，第 20 号、pp. 42-43，1996

18）谷口賛, 桜井慎一, 安達一慶 : ウォーターフロントで許容される建築物 の色彩の研究一その 1 建築物の色彩の騒色基準一, 日本建築学会大会学 術講梗概集，構造系，pp. 413-414，2002.8

19）中野雄大, 中井祐: 景観色彩問題の事例分析に基づく色彩規制の在り方 に関する考察，景観・デザイン研究講演集，第 10 号，pp. 10-13，2009

20）三星宗雄: 日本に扔ける騒色公害とその解決, 神奈川大学人文学研究所 報，第 42 号，pp. 35-51，2011.10

21）小島武男，中村洋，稲垣卓造，岡本敏嗣：アクセント色に関寸実験の研 究 1一明度対比について一, 日本建築学会大会学術講演梗概集, pp. 153$154,1976.10$

22）山本浩史, 熊澤貴之 : 建築外部の色彩構成が町並の評価に与える影響, 日本建築学会大会学術講演梗概集, 環境工学 I, pp. 439-440, 2011.8

23）熊澤貴之: 商業系市街地における建築外部のアクセント色が街路景観評 価に与える効果一倉敷駅前景観を事例としてー, 日本建築学会環境系論 文集，第 78 号，pp. 103-110，2013.2

24）熊澤貴之, 山本早里, 槙究 : 周辺環境色の調和を考慮した景観色彩設計 法の有効性, 日本建築学会大会学術講演梗概集, 環境工学 I, pp. 521524, 2014

25）辻大輔，山崎正史: 京都市都心部における屋外広告物の現状と規制に関 する研究, 日本建築学会大会学術講梗概集, 都市計画, pp. 1111-1112, 2004. 8

26）加藤光彦, 石井悠香, 伊藤美喜, 平尾和洋 : 景観写真のメッシュデータ による屋外広告物の色彩分布に関する研究, 日本建築学会近畿支部研究 報告集，pp：613-616，2003

27）勝矢佳子, 石田泰一郎 : 屋外広告物が都市景観の視覚的な印象に与える 影響一京都市の屋外広告物規制区域について一, 日本建築学会大会学術 講梗概集，環境工学 I, pp. 455-456, 1999.9

28）土屋宽恭，川角典弘，吉田知央：屋外広告物に上る景観色彩の印象評価 に関する研究, 日本建築学会大会学術講梗概集, 建築計画 I, pp. 725-726, 2008. 9

29）平尾和洋，瀬川貴世，渡部しつか：街路景観シミュレーション・評価に よる屋外広告物の適正規模・色彩に関する研究，日本建築学会近畿支部 研究報告集計画系, 第 43 号, pp : 617-618, 2003.5

30）谷口みゆき, 澤一寬: 屋外広告物の色彩研究一地域別掲出傾向の調查一, 日本色彩学会誌，第 23 号，pp. 62-63，1999

31）渡辺安心, 沖中忠太朗, 藤井秀雪, 高畑吉博, 村上幸三郎, 吉田秀雄: 京都にふさわしい屋外広告物の色彩, 日本色彩学会誌, 第 34 号, pp. 3031,2010

32）佐藤優，金英美 : 屋外広告物の色彩の制御方法に関する研究，デザイン 学研究, 第 43 号, pp. 41-48, 1996. 5

33）槙究: 看板の色変更に関する研究一町並との調和・視認性・ロゴアイデ ンティティの観点からー, 日本建築学会環境系論文集, 第 77 号, pp:941948, 2012.12

34）庄怡, 山本早里:配色要素が建物の印象に及ぼす影響, 日本色彩学会誌, 第 39 号，pp. 22-24，2015.9

35）佐藤仁人, 中山和美, 名取和幸: 壁面色の面積効果に関する研究, 日本 建築学計画系論文集，第 555 号，pp. 15-20，2002.5

\section{Note}

a) 'Clashing color' is an approximate translation by the authors of '騒色'. In Japanese they are described as 公共の色彩を考える会, i.e., objectionable color combinations which are disturbing to the local color environment and are perceived negatively. In the worst cases, they result in emotional distress, and can be the cause of health issues. 


\section{和文要約}

2014 年に、イタリア、フランス、日本、中国において、国や町で 公表されている景観計画や色彩計画を調査した。その結果、町の色 をコントロールする方法は使用する色の值を決めることを中心に実 施されているが、色の使用面積、基調色の使用頻度、色の使用部位 も町の雰囲気に影響を与えていることが分かった。区域に分けて基 準を設定する方法は共通しており、中でも歴史的な区域の色彩は一 番厳しく制限されていることが明らかとなった。

現状では、コーポレートカラーなどの様々な色を建物に使いたい という需要が多い。新しい色もしくは町の色彩基準に制限されてい る色の使用に関して、そのまま使われるか、行政の色彩基準に沿っ て直されているのが現状である。そのまま使われると騒色になる例 が多い。一方で色彩基準通りに直されると、色彩に関する個の特徵 は尊重されず、生活の利便性が失われるとも言われている。

現状の色彩基準をみると、歴史的な区域では小面積に新しい色を 導入する傾向が見られるが、面積に応じた色彩の使用方法はまだ決 められていない。規制している色彩は、色相に関してはR〜Yと他の 色相に分けていることが多かったが、それぞれの色相と面積の関係 は検証されていない。一方、中国では、広告物の色に関する条例は まだ実施されていない。

先行研究は 1) 町の色彩計画 ; 2) 騒色事例及びその対策 ; 3) アク セント色；4)看板色の規制の実態と評価構造に分けられる。これま での色彩計画に関する研究は主に地域の個性を重視し、全体の調和 を目指している。その中で、小面積に使える色や、色と面積との関 係は述心゙られていない。屋外広告物の色に関する実験は面積、色の 彩度を中心に実験されている。しかし、色相、明度、彩度及び面積 との関係性の考察はまだ見られない。

本研究は、色彩計画を行っている歴史的な地区における屋外広告 の色に着目し、色彩コントロール方法の一つとして、色相、明度、 彩度と使用面積との関係性を考察していく。つまり、それぞれの面 積によって許容できる色相の明度と彩度を明らかにする。

歴史的建物として代表的な木造と白壁の建物を想定し、中国と日 本の建物の類似性と差異を考え、中国周庄の白壁と日本京都の木造 建築を参考にした。アンケート実験で、この二つの街並をもとにし た立面図を用い、印象評価実験を行った。建物 3 件からなる街並の 立面図で、図 $1 \sim 2$ に示したように、中央の 1 件の 1 階庇上の屋外 広告の色を変化させた。今回実験に使った色は 26 色であり、面積

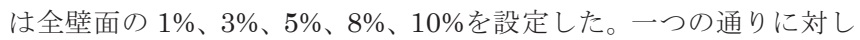
て屋外広告の色彩・面積を変化させた 66 枚の図版を作成し、二つ の通りで合計 132 枚の図版である。図版を 1 枚ずつ被験者に提示 し、7 段階の SD 法で評価させた。それぞれの回答に数值を対応さ せ、分析を行った。

第 3 章では、実験者背景、評価項目の分析を行った。その結果、 被験者の属性による有意差がなく、全体的な回答の傾向が一致して いた。そして、評価項目「伝統」、「調和」と「許容」は高い正の相 関があった。そのため、データ分析は「許容」の平均值を利用し、 色相、明度、彩度と使用面積の関係を検討してきた。回答に有意差 があり、そして評価の值に正負の変化があることを基準として、面 積別に許容できる明度、彩度、色相を分析した。分析の最後は、色 による面積別の許容度の変化について検討した。
今回の実験では、京都の木造建築と周庄の白壁建築の結果で以下 の点に類似性があった。

明度については、彩度 4 の場合、 $\mathrm{R}$ 系、 $\mathrm{Y}$ 系、 $\mathrm{B}$ 系、 $\mathrm{N}$ 系の明度 の許容度を検証した。有彩色では、 $\mathrm{R}$ 系と $\mathrm{Y}$ 系の明度は 6 以上に、 $\mathrm{B}$ 系は明度 3 以上になると、許容度が 0 以下になり、つまり許容で きないと考えられる。無彩色に対する許容はその差がない。

有彩色の場合、面積 $3 \%$ 以内、明度 3 、彩度 6 以下、色相 $R 、 Y$ 、 $\mathrm{B}$ の色に対する許容は類似していた。色相 $\mathrm{G}$ と $\mathrm{P}$ における許容でき る色の彩度はこれに比べて低かった。

このように、木造建築と白壁建築で共通している許容色を表 2 の ようにまとめることができた。一方で、2 種類の街並では、色に対 する許容の差は色相 Y に見られた。面積 $10 \%$ 、彩度 6 の場合、色相 $\mathrm{Y}$ に対する許容度は京都の木造の建築のほうが高かった。最後に、 今回の実験で使用した面積 $10 \%$ 以内では、各色による面積別の許容 は中国白壁の建物における 2 色しか有意差が出なかった。つまり、 面積より、色の色相、明度、彩度が町の印象に影響を与えていた。

実験結果から見ると、歴史的な材料色に対する許容度が高かった。 このように、歴史的な地域において、さらに色を自由に、効果的に 使う可能性が得られた。

（2016 年 5 月 9 日原稿受理， 2016 年 11 月 14 日採用決定） 